\title{
Effects of Enterprise Skills Training for Women Processing Cassava (Gari) in Asa Local Government Area of Kwara State
}

\author{
AWOYEMI, Samson Oyebode ${ }^{1}$ \\ Agricultural And Rural Management Training Institute \\ P.M.B. 1343, Ilorin, Kwara State, Nigeria \\ FADAYOMI, Akinwumi Festus ${ }^{2}$ \\ Department of Statistics, Federal School of Statistics, Ibadan Campus \\ Ajibode Shasha Road, Ibadan \\ P. O. Box 20753, U. I Post office, Ibadan Nigeria \\ AFOLABI, Olushola Festus ${ }^{1}$ \\ and \\ AKINYEKE, Francis ${ }^{2}$ \\ Department of Business Administration and Management
}

\begin{abstract}
This study was designed to estimate the effect of training among the rural women processing Gari in Asa Local Government Area of Kwara state, Nigeria. Primary data was used and purposive sampling procedure was adopted for the population of women involved at any stage of Gari processing activities. A total of 232 respondents were interviewed the data collected were analyzed using both descriptive and inferential analytical techniques. Findings revealed that these women specialized in various activities of Gari making process that is about $49.1 \%$ specialized in frying while $10.8 \%$ were engaged in peeling grinding and Jacking of peeled cassava and about $22.8 \%$ of them were involved in marketing of the finished products. It was also discovered that statistical significance difference exist between those women who had opportunity to be trained compare with those that has not been exposed to any form of training, in terms of increased income generation and employment creation. In conclusion, We recommend that policy Makers need to ensure that agriculture and Enterprise Training be made prominent in Government interventions.
\end{abstract}

Keywords: Enterprise Training, Gari, Cassava

DOI: $10.7176 / \mathrm{EJBM} / 13-14-04$

Publication date:July $31^{\text {st }} 2021$

\section{Enterprise Training}

1.0 Background to the study:

An enterprising nation can tackle the economic downturn head on by nurturing skills. For any country to compete favourably with global emerging trends is to promptly address what she can do to support enterprise and businesses so that financial growth and prosperity increases, in the U.K, Leitkh, P. (2001) recommendations have since been updated to encourage the re-sculling of workforces for recovery and formulating the best practices to implement skills and training policies.

Tikly et al. (2003) said "the promotion of skills for modernized, productive farming goes hand in hand with a call for immediate training in skills to decrease dependence on agriculture, in the form of craft, artisan and entrepreneurial skills".

Rural women are a relative term used to mean a peasant rural based farmers. They constitute over 85 percent of the rural population (census 2006) mainly tilling the land and contributing 92 percent of the nations agricultural produce. There is an imbalance against the rural women's participation in development although they are pillars of rural and national development due to gaps in entrepreneurship training.

Palmer, R (2007) has said the integrating enterprise training into agricultural development initiatives help small holders make more money out of agriculture.

\section{Enterprise Skills and Diversification in the Rural Economy}

Despite the growing importance of small entrepreunal skills in economic activity, the country still remains dominated by large foreign firms. In Nigeria only a handful of SMEs grow rapidly into large firms. It is therefore important to identify the Central factors which lie behind that phenomenon and the particular links which may be made between training, and business growth and financial performance. In discussing this paper noted that SMEs in this country are relatively more constrained by management skills than they are by financial market failures, and that management competence and skills issues may be a key factor in preventing growth/innovations. 
Apprenticeships can play a pivotal role in developing the skills needed to succeed in work place and building residences. A service driven, knowledge-based workforce can be encouraged to develop innovations and integrate initiatives.

\section{Benefits of Enterprise Training}

These include:

- Everyone is aware of the expectations and can achieve smoothly.

- Trained people are also more confident in their performance and decision-making skills.

- Training is more likely to accept change and come up with new ideas.

- They will be equipped with the available opportunities and constraints together with practical solutions to running an efficient, effective business in turbulent, economic times.

United Nation Capital Development Fund (UNCDF) advocates the need to create awareness for support for microfinance as access to financial services increases economic security and contributes to the achievement of the millennium development Goals (MDGs) by allowing people to:

- Invest in future

- $\quad$ Build Assets and diversify income stream

- Respond to economic opportunity

- $\quad$ Cope with hardship and manage risks.

These are not possible unless adequate steps are taken in Capacity building and entrepreneurial training of rural dwellers who constitute a greater percentage of the entire population, (census 2006). Increased awareness and understanding of the need for rural women to acquire certain skills and develop expertise through activities such as business coaching hands - on training and ICT training that is needed to promote and increase entrepreneurial skills of the rural women so as to empower these women to become successful entrepreneurs is therefore imperative. The objective of this study therefore is to assess impact of various training opportunities and training interventions of both government Non government organizations (NGOs) on the profitability of enterprises in Asa local Government.

\section{Materials and Method}

This study uses samples collected from the Agrarian Communities in Asa Local government area in Kwara state Nigeria. Its headquarters are in the town of Afon. It has an area of 1,286 km and a population of about 126,435 mostly crop farmers. The Local government shared boundaries with Oyo and Osun state in the south and East respectively while the North and Western part of the local Government boundary is with Ilorin West and Ifelodun Local government of the same State (Kwara).

Primary Data was collected from about 232 women using purposive sampling procedure from the towns and villages in the Local government

\section{Results and Discussions \\ Demographic Characteristics}

Data presented in Table 1 shows the characteristics of these women processing cassava in Asa Local Government. Majority (66.3\%) are still in their working age that is between 21-50 years of age, this which means that majority of these women are still active in their productive age whatever intervention given to them will be adequately utilized. In addition it can also be seen that about $84.8 \%$ are either single or married, culturally this show the high level of responsibility and a pointer to the fact that these women possess trainable traits. The level of western education of these rural women reveals that more than $59 \%$ have never enters into the four walls of the classroom and this must have had serious impact on the productivity of those groups of women. The table also revealed the years of experience of these women in Gari processing activities, and it was discovered that more than 54\% had more than eleven (11) years of experience, infact many of them learn the art from their parents at cradle. 
Distribution of Respondents by Characteristics

Table 1

\begin{tabular}{|c|c|c|}
\hline Demographic Characteristic & Frequency & Percentage \\
\hline $\begin{array}{l}\text { Age } \\
<20 \\
21-30 \\
31-40 \\
41-50 \\
750\end{array}$ & $\begin{array}{l}38 \\
82 \\
70 \\
48 \\
64\end{array}$ & $\begin{array}{l}12.6 \\
27.2 \\
23.1 \\
15.9 \\
21.2\end{array}$ \\
\hline $\begin{array}{l}\text { Marital Status } \\
\text { Single } \\
\text { Married } \\
\text { Separated/Divorced } \\
\text { Widowed }\end{array}$ & $\begin{array}{l}132 \\
124 \\
22 \\
24\end{array}$ & $\begin{array}{l}43.7 \\
41.1 \\
7.3 \\
7.9\end{array}$ \\
\hline $\begin{array}{l}\text { Religion } \\
\text { Christianity } \\
\text { Islam } \\
\text { Traditional }\end{array}$ & $\begin{array}{l}68 \\
164 \\
70\end{array}$ & $\begin{array}{l}22.5 \\
54.3 \\
23.2\end{array}$ \\
\hline $\begin{array}{l}\text { Household Size } \\
1-2 \\
3-4 \\
74\end{array}$ & $\begin{array}{l}63 \\
127 \\
112\end{array}$ & $\begin{array}{l}20.8 \\
42.1 \\
37.1\end{array}$ \\
\hline $\begin{array}{l}\text { Level of education } \\
\text { Tertiary } \\
\text { Secondary } \\
\text { Primary } \\
\text { Not at all }\end{array}$ & $\begin{array}{l}0 \\
18 \\
76 \\
138\end{array}$ & $\begin{array}{l}0 \\
7.7 \\
32.8 \\
59.5\end{array}$ \\
\hline $\begin{array}{l}\text { Years of Experience } \\
1-10 \\
11-20 \\
720\end{array}$ & $\begin{array}{l}108 \\
69 \\
55 \\
\end{array}$ & $\begin{array}{l}46.6 \\
29.7 \\
23.7 \\
\end{array}$ \\
\hline
\end{tabular}

Source: Field survey, 2014

The result analysis on the Distribution of respondents by skills indicated that majority of these women ( more than forty-nine percent $49.1 \%$ ) were involved in frying activity followed by marketing which account for about $22.8 \%$.

Evidence from the data analysis presented in table 3 showed that more than $89 \%$ of the women learn the job and has never attended any formal training at all since they entered into business, and only about $10.8 \%$ had one form of opportunity or the other to attend workshop(s) organize by either the state, local government or by an NGOs.

Despite the number of years on the job of these women it can be seen from Table 4: that majority of the women has their business worth less than or equal to N100, 000 (that is about 59.1\%) and none of them has a business worth up to N500.00 this is an indication of serious poverty among the women processing Gari in Asa local government of Kwara State.

Table 2: Distribution of Respondents by Skills

\begin{tabular}{|l|l|l|}
\hline Type of Involvement & Frequency & Percentage \\
\hline Cassava cultivation & 18 & 7.8 \\
Middle Men & 22 & 9.5 \\
Grinding Machine and Jack Operator & 25 & 10.8 \\
Frying & 144 & 49.1 \\
Marketing & 53 & 22.8 \\
\hline
\end{tabular}

\section{Source: Field Survey 2014}

Table: 3 Distribution of Respondents by Special Training(s) Received

Extension Agents from State government

Extension Agents from Local government

Training by NGOs

On-Job Training

\begin{tabular}{|l|l|}
\hline Frequency & Percentage \\
\hline 4 & 1.7 \\
10 & 2.2 \\
10 & 403 \\
207 & 89.2 \\
\hline
\end{tabular}

Source: Field Survey, 2014 
Table 4: Distribution of Respondents by Worth of Business

\begin{tabular}{|l|l|l|}
\hline Present Worth $(\mathrm{N})$ & Frequency & Percentage \\
\hline$<100,000$ & 137 & 59.1 \\
$100,001-200,000$ & 58 & 25 \\
$2000,001-400,000$ & 32 & 13.8 \\
$400,001-500,000$ & 5 & 2.1 \\
$>500,000$ & Nil & Nil \\
\hline
\end{tabular}

\section{Source: field survey 2014}

\section{Test of Hypothesis}

Two hypotheses were tested in the study. They are:

1. Difference, between the trained and the group that were not trained

2. Difference between good record keeping and those that refuse to keep record.

The hypotheses are stated and tested as follows:

Hypothesis one: $\mathrm{H}_{0}: \mu_{1}=\mu_{2}=\mu_{3}$ Vs Ha: Not $\mathrm{H}_{0}$. There is no significant difference between different categories of women processing gari that is those trained by the NGO, those trained by the government and those (state or local) without formal training at all.

\section{ANOVA}

Table 5: showed that there is statistically significant difference among the trained and trained not since $\mathrm{P}=$ 0.000 , this value compared with the level of significance of $\mathrm{P}=0.05$ is less. Then we can conclude that there is significant difference in profit margin 00 the trained and the trained not.

Table: 6 (post hoc test revealed) that difference exist either you are trained by the state or local government. There is difference in performance and profit. When compared with the category that has not been trained at all.

Table 5: Annual Profit ' 0000'

\section{ANOVA}

\begin{tabular}{|l|r|r|r|r|r|}
\hline & Sum of Squares & df & Mean Square & F & Sig. \\
\hline Between Groups & 8526.291 & 2 & 4263.145 & 105.169 & .000 \\
Within Groups & 9282.813 & 229 & 40.536 & & \\
Total & 17809.103 & 231 & & & \\
\hline
\end{tabular}

Source: Field Survey, 2014.

Table 6: Dependent Variable: Annual Profit ' 0000'

\section{Multiple Comparisons}

Tukey HSD

\begin{tabular}{|c|c|c|c|c|c|c|}
\hline \multirow[b]{2}{*}{ (I) TRAINING } & \multirow[b]{2}{*}{ (J) TRAINING } & \multirow{2}{*}{$\begin{array}{c}\text { Mean } \\
\text { Difference (I- } \\
\mathrm{J})\end{array}$} & \multirow[b]{2}{*}{$\begin{array}{l}\text { Std. } \\
\text { Error }\end{array}$} & \multirow[b]{2}{*}{ Sig. } & \multicolumn{2}{|c|}{$\begin{array}{c}95 \% \text { Confidence } \\
\text { Interval } \\
\end{array}$} \\
\hline & & & & & $\begin{array}{l}\text { Lower } \\
\text { Bound }\end{array}$ & $\begin{array}{l}\text { Upper } \\
\text { Bound }\end{array}$ \\
\hline \multirow{2}{*}{$\begin{array}{l}\text { Attended at least one } \\
\text { Training Programme by } \\
\text { NGO }\end{array}$} & $\begin{array}{l}\text { Attended at least oneTraining } \\
\text { prog ramme by Govt }\end{array}$ & -6.509 & 3.241 & .112 & -14.15 & 1.14 \\
\hline & No Formal Training & 5.729 & 3.237 & .182 & -1.91 & 13.36 \\
\hline \multirow{2}{*}{$\begin{array}{l}\text { Attended at } \\
\text { oneTraining } \\
\text { ramme by Govt }\end{array}$} & $\begin{array}{l}\text { Attended at least one Training } \\
\text { Programme by NGO }\end{array}$ & 6.509 & 3.241 & .112 & -1.14 & 14.15 \\
\hline & No Formal Training & $12.238^{*}$ & .844 & .000 & 10.25 & 14.23 \\
\hline \multirow[t]{2}{*}{ No Formal Training } & $\begin{array}{l}\text { Attended at least one Training } \\
\text { Programme by NGO }\end{array}$ & -5.729 & 3.237 & .182 & -13.36 & 1.91 \\
\hline & $\begin{array}{l}\text { Attended at least oneTraining } \\
\text { prog ramme by Govt }\end{array}$ & $-12.238^{*}$ & .844 & .000 & -14.23 & -10.25 \\
\hline
\end{tabular}

*. The mean difference is significant at the 0.05 level.

Source: Field Survey, 2014.

Hypothesis 2: Ho: $\mu_{1}=\mu_{2}=: \mu_{3} V_{s} H_{a}$ : Not $H_{0}$. There is no significant difference between the profit margin of these women that keep adequate records in business and those that cannot. 
Table: 7

ANOVA
Annual Profit ' 0000'
\begin{tabular}{|l|r|r|r|r|r|}
\hline & Sum of Squares & df & Mean Square & \multicolumn{1}{|c|}{ F } & Sig. \\
\hline Between Groups & 3025.306 & 2 & 1512.653 & 23.431 & .000 \\
Within Groups & 14783.798 & 229 & 64.558 & & \\
Total & 17809.103 & 231 & & & \\
\hline
\end{tabular}

Source: Field Survey, 2014

Table 7 and 8 showed the comparison of the means of profit in term of division by records and the post-hoc test which tells us where the difference actually lie.

Table 7 revealed a significance value of 0.000 and this is less than the significance level of $\mathrm{P}=0.05$, this which implies that a significant difference exist in the amount of profit made by the record keepers, and Table 8 showed that this difference exist significantly and those that did not keep record at all.

Table 8:

Multiple Comparisons

Dependent Variable: Annual Profit ' 0000'

Tukey HSD

\begin{tabular}{|c|c|c|c|c|c|c|}
\hline \multirow[b]{2}{*}{ (I) RECORDS } & \multirow[b]{2}{*}{ (J) RECORDS } & \multirow{2}{*}{$\begin{array}{c}\text { Mean } \\
\text { Difference (I- } \\
\mathrm{J})\end{array}$} & \multirow[b]{2}{*}{$\begin{array}{l}\text { Std. } \\
\text { Error }\end{array}$} & \multirow[b]{2}{*}{ Sig. } & \multicolumn{2}{|c|}{$\begin{array}{l}95 \% \text { Confidence } \\
\text { Interval } \\
\end{array}$} \\
\hline & & & & & $\begin{array}{l}\text { Lower } \\
\text { Bound }\end{array}$ & $\begin{array}{l}\text { Upper } \\
\text { Bound }\end{array}$ \\
\hline \multirow[t]{2}{*}{$\begin{array}{l}\text { KEEP RECC } \\
\text { ADEQUQTELY }\end{array}$} & $\begin{array}{l}\text { DONT KNOW ABOUT } \\
\text { RECORD KEEPING }\end{array}$ & -.687 & 1.568 & .900 & -4.39 & 3.01 \\
\hline & $\begin{array}{l}\text { DONT KEEP RECORD } \\
\text { AT ALL }\end{array}$ & $7.964^{*}$ & 1.792 & .000 & 3.74 & 12.19 \\
\hline \multirow[t]{2}{*}{$\begin{array}{l}\text { DONT KNOW ABOUT } \\
\text { RECORD KEEPING }\end{array}$} & $\begin{array}{l}\text { KEEP RECORD } \\
\text { ADEQUQTELY }\end{array}$ & .687 & 1.568 & .900 & -3.01 & 4.39 \\
\hline & $\begin{array}{l}\text { DONT KEEP RECORD } \\
\text { AT ALL }\end{array}$ & $8.651^{*}$ & 1.280 & .000 & 5.63 & 11.67 \\
\hline \multirow[t]{2}{*}{$\begin{array}{l}\text { DONT KEEP RECORD } \\
\text { AT ALL }\end{array}$} & $\begin{array}{l}\text { KEEP RECORD } \\
\text { ADEQUQTELY }\end{array}$ & $-7.964^{*}$ & 1.792 & .000 & -12.19 & -3.74 \\
\hline & $\begin{array}{l}\text { DONT KNOW ABOUT } \\
\text { RECORD KEEPING }\end{array}$ & $-8.651^{*}$ & 1.280 & .000 & -11.67 & -5.63 \\
\hline
\end{tabular}

*. The mean difference is significant at the 0.05 level.

Source: Field Survey, 2014

\section{Conclusion and Recommendation}

The following from the results emanating from the study, conclusions are drawn that both agriculture and enterprise training are required to support rural development.

$>$ There was no regular training and advisory services to ensure scaling is made prominent in Government interventions

$>$ Policy makers need to ensure that agriculture and enterprise training be made prominent in Government interventions

$>$ Attention needs to be paid to ensuring that trainers have the skills to deliver integrated training with proper Adult Learning Techniques.

\section{References}

Tickly, L J. Love, M. Crosslay, H. Dachi, R Gareth and B. Mukabaranga (2003)Globalisation and skills for Development in Rwanda and Tanzania DFID educational papers N0 51.

Palmer, R (2007 Skills development, the enabling environment and informal micro enterprise in Ghana. PhD University of Edinburgh.

Leitkh; P. (2001) Guide to Rural Economic and Enterprise Development.

Kathleen Collett (2010) City and Guild Centre for skills Development (Instills@ development.org). 